\title{
Erratum to: Problem Anger in Psychotherapy: An Emotion-Focused Perspective on Hate, Rage, and Rejecting Anger
}

\author{
Antonio Pascual-Leone • Phoenix Gillis • \\ Terence Singh • Cristina A. Andreescu
}

Published online: 8 November 2012

(C) Springer Science+Business Media New York 2012

Erratum to: J Contemp Psychother

DOI 10.1007/s10879-012-9214-8

The last name of the second author of this article, Phoenix Gillis, was misspelled in the article as published. Please note that the correct spelling of the last name of the second author of this article is in fact "Gillis" (not "Gilles").

The online version of the original article can be found under doi:10.1007/s10879-012-9214-8.

A. Pascual-Leone · P. Gillis $(\bowtie) \cdot$ T. Singh · C. A. Andreescu Department of Psychology, University of Windsor, 401 Sunset Avenue, Windsor, ON N9B 3P4, Canada

e-mail: gillise@uwindsor.ca

A. Pascual-Leone

e-mail: apl@uwindsor.ca 